\title{
THE ABILITY OF LACTOBACILLUS RHAMNOSUS TO BIND PATULIN AND ITS APPLICATION IN APPLE JUICE
}

\author{
J. Lia ${ }^{a}$ L. LIU \\ ${ }^{a}$ Heilongjiang Green Food Research Institute, Harbin 150030. China \\ ${ }^{\mathrm{b}}$ Institute of Animal Science of CAAS, Beijing 100193. China \\ ${ }^{\mathrm{c}}$ Key Laboratory of Dairy Sciences, College of Food Sciences, Northeast Agricultural University, Harbin 150030. \\ China
}

(Received: 25 July 2019; accepted: 4 December, 2019)

The purpose of this study was to evaluate the ability of Lactobacillus rhamnosus to bind patulin (PAT) in the buffer solution and apple juice. The binding of L. rhamnosus to PAT was reversible, which improved the stability of the bacterial complex. The ability to bind PAT can be enhanced with the inactivation of the strain by high temperature and acid treatment. Acid-treated bacteria had the highest PAT binding rate of $72.73 \pm 1.05 \%$. The binding rates of acid and high temperature $\left(121{ }^{\circ} \mathrm{C}\right)$ treatments were increased by $21.37 \%$ and $19.15 \%$, respectively. L. rhamnosus showed the best detoxification ability to PAT at $37{ }^{\circ} \mathrm{C}$, where the binding rate reached $50.9 \pm 1.03 \%$. When the dose of inactivated bacteria powder was $0.02 \mathrm{~g} \mathrm{ml}^{-1}$, the minimum concentration of PAT in apple juice was $0.37 \mu \mathrm{g} \mathrm{m}{ }^{-1}$. The addition of the L. rhamnosus inactivated powder did not affect the quality of the juice product and effectively bound the PAT in apple juice.

Keywords: Lactobacillus rhamnosus, patulin, adsorption, complex, apple juice

Patulin (PAT) is a secondary metabolite produced by fungal species belonging to Penicillium, Eupenicillium, and Paecilomyces genera. As one of the most studied mycotoxins, PAT has carcinogenic, teratogenic, and mutagenic effects in humans and animals (DRUSCH et al., 2007). A maximum tolerable daily intake for PAT of $0.4 \mathrm{mg}$ per $\mathrm{kg}$ (body weight) has been established by FAO (ZoGHI et al., 2017). PAT is heavily contaminating fruits and their processed products, especially apple products (BONERBA et al., 2010). EC (2003) has set a maximum acceptable PAT concentration of $50 \mu \mathrm{g}^{-1}$ in apple juices. Therefore, the control of PAT in food is of vital importance for food safety.

The common techniques for the binding of toxins in food are divided into physical, chemical, and biological methods (CATALDO, 2008). Toxins can be partially bound by physical methods, but those have undesirable effects on the nutrient composition and flavor of food. At binding, the structure of the toxin is changed. The use of lactic acid bacteria (LAB) for adsorption is in the focus of studies nowadays. LAB can effectively bind aflatoxin M1 in milk (ELSANHOTY et al., 2014) by adsorbing toxins on cell wall polysaccharides, peptides, and surface proteins by intermolecular interactions (SERRANO-NiÑo et al., 2013). At present, there are few reports about the effect of L. rhamnosus on the binding of PAT. Our aim was to study the ability of L. rhamnosus to bind PAT. In this work, the cell surface morphology and stability of LAB/PAT complex were observed after high temperature, acid and alkali treatments of L. rhamnosus. The detoxification ability of different cell components was also compared. The ability of L. rhamnosus to bind PAT from apple juice and its effect on the quality of apple juice were evaluated.

\footnotetext{
* To whom correspondence should be addressed.

E-mail: liboliu@126.com
} 


\section{Materials and methods}

\subsection{Preparation of bacterial strains and treatments}

L. rhamnosus 08066 used in the experiment was provided by the Key Laboratory of Dairy Science, Northeast Agricultural University. The ability of the strain to bind PAT in contaminated PBS was tested and simultaneously a growth curve was determined by measuring the absorbance at $600 \mathrm{~nm}$. Bacterial pellets were collected by centrifugation $\left(8000 \times g, 4{ }^{\circ} \mathrm{C}, 10 \mathrm{~min}\right)$ and washed three times with $4 \mathrm{ml}$ PBS (pH 6.0) before further processing. The above bacteria were subjected to high temperature treatment (boiling in $4 \mathrm{ml}$ of PBS for $1 \mathrm{~h}$, sterilization in $4 \mathrm{ml}$ of PBS for $1 \mathrm{~h}$ at $121^{\circ} \mathrm{C}$ ), acid treatment (sterilization in $4 \mathrm{ml}$ of $2 \mathrm{M} \mathrm{HCl}$ for $1 \mathrm{~h}$ ), and alkali treatment (sterilization in $4 \mathrm{ml}$ of $2 \mathrm{M} \mathrm{NaOH}, 1 \mathrm{~h}$ ).

\subsection{Preparation of cellular components}

Cell disruption was carried out in an ice bath using ultrasonication. The precipitate was collected by centrifugation $\left(8000 \times \mathrm{g}, 4{ }^{\circ} \mathrm{C}, 10 \mathrm{~min}\right)$. Protoplasts, superficial proteins, and peptidoglycans were determined according to the reported methods (HASKARD et al., 2000). The samples were lyophilized and stored at $-20^{\circ} \mathrm{C}$ until use (BRACKETT et al., 1979).

\subsection{PAT binding assay}

The PAT standard solution was prepared in different concentrations (VAN EMMERIK et al., 2010). The bacteria and cell components were suspended in $2 \mathrm{ml}$ PBS containing PAT and incubated for $8 \mathrm{~h}$ at $37^{\circ} \mathrm{C}$. After centrifugation $(3000 \times g, 15 \mathrm{~min})$, the supernatant was taken to determine PAT content. The detection was carried out by high performance liquid chromatography (HPLC Waters $6000^{\circledR}$ ).

\subsection{Morphological observation of bacterial surface}

The treated cell pellet was fixed in $2.5 \%$ glutaraldehyde and $1 \%$ citric acid. The cells were dehydrated, embedded, sliced, and finally stained with uranyl acetate and lead citrate to obtain bacterial sections. The changes of cell in different treatment methods were observed by transmission electron microscopy (TEM) (ZHANG et al., 2018).

\subsection{Factors affecting the ability of binding}

The cells were suspended in $2 \mathrm{ml}$ of PBS with different $\mathrm{pH}$ values. After adding 100, 250, 500,1000 , and $1500 \mathrm{ng} \mathrm{ml}^{-1} \mathrm{PAT}$, the concentrations of the adjusted solution were $2.5 \times 10^{9}$, $5 \times 10^{9}, 7.5 \times 10^{9}, 1 \times 10^{10}$, and $1.25 \times 10^{10} \mathrm{CFU} \mathrm{ml}^{-1}$. The suspensions were mixed at $4,15,25$, $37,42{ }^{\circ} \mathrm{C}$, respectively, and cultured in a shaker at 200 r.p.m. for $7 \mathrm{~h}$, PAT content was determined every $1 \mathrm{~h}$ (HASKARD et al., 2001).

\subsection{Combination of apple juice and PAT}

The experimental strain was killed by high temperature. The precipitate was collected by centrifugation and lyophilized for use. Different doses of the above powders were resuspended in $100 \mathrm{ml}$ of apple juice containing $1 \mu \mathrm{g} \mathrm{ml}{ }^{-1} \mathrm{PAT}$ at $37^{\circ} \mathrm{C}$. The cells were cultured for $4 \mathrm{~h}$ in a shaker, and the supernatant was collected by centrifugation for further analysis (RICELLI et 
al., 2007). The colour value and light transmittance of juice were measured using a spectrophotometer at $440 \mathrm{~nm}$ and $625 \mathrm{~nm}$, respectively. The $\mathrm{pH}$ value was measured by a micro-pH meter. Soluble solids were determined using a hand-held refractometer. Measurement of total sugar and total acid were carried out according to the SB/T 10203-1994 standard.

\subsection{Data analysis}

Data processing was performed using SPSS 22.0. The results were expressed as mean \pm standard deviation $(\mathrm{X} \pm \mathrm{SD})$. Comparisons between groups were done with conventional oneway analysis of variance (ANOVA), which were judged to be different at $\mathrm{P}<0.05$.

\section{Results and discussion}

\subsection{Effect of treatment on PAT binding}

Results of PAT binding rate by the differently treated bacteria are shown in Figure 1. HCltreated bacteria had the highest PAT binding rate $(72.73 \pm 1.05 \%)$, followed by heat-treated $\left(121^{\circ} \mathrm{C}, 70.51 \pm 0.25 \%\right)$ ones. There were significant differences in the acid treatment and heat treatment compared with the control $(\mathrm{P}<0.05)$. After alkali treatment, the detoxification ability of the cells slightly improved. Four bacterial treatments had improved the adsorption effect to varying degrees. HASKARD and co-workers (2000) added anti-hydrophobic agents to heat-treated and acid-treated strains; the binding effect was greatly reduced, demonstrating that the binding was closely related to the hydrophobic interaction. Generally, heat treatment and acid treatment resulted in denaturation of the cell wall protein of the strain, which led to the surface of the cell wall exposing more hydrophobic regions, thus enhancing the ability of the bacteria to bind toxins (MAHAM et al., 2013).

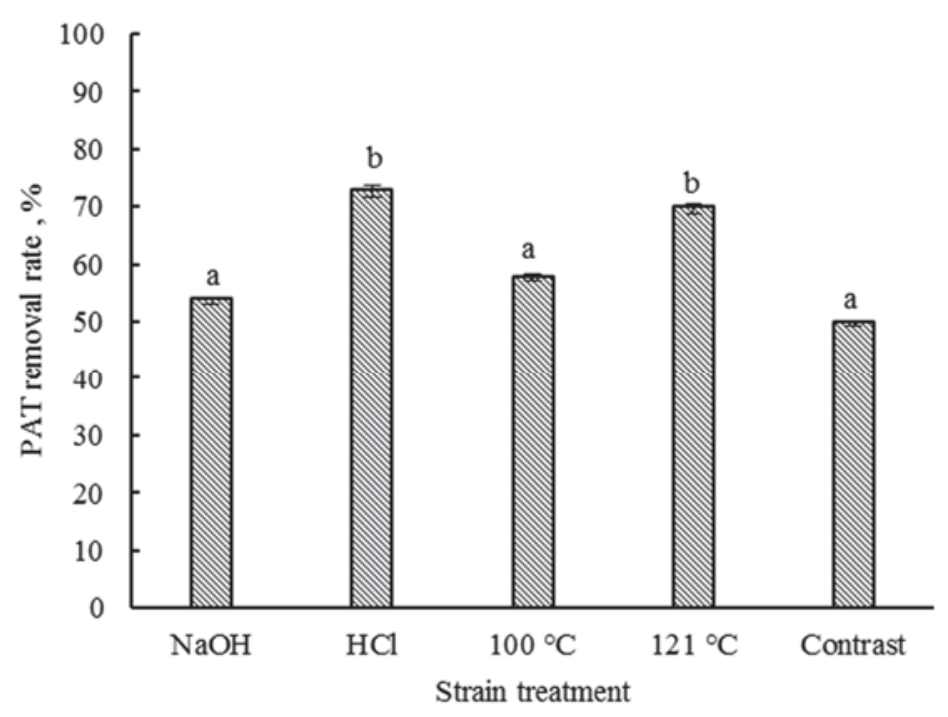

Fig. 1. Effects of different treatments of L. rhamnosus on patulin binding rate 
The changes of bacteria after treatment with acid, alkali, and heat are presented in Figure 2. Compared with normal bacterial cells, the surface of the treated cells had different degrees of change. Figure 2A shows the surface of the normal cells having a uniform tooth shape, a clear outline, and a smooth cell wall with uniform thickness. Figure $2 \mathrm{~B}$ shows the acidtreated cells. The granules on the surface of the acid-treated bacteria were fuzzy, and the cell walls became fluffy. In some places, the cell walls even disappeared and formed flocs on the surface; Figure 2C shows the alkali-treated cells. The surface of the treated bacteria was severely carbonized, and almost all of the cells were lysed and fragmented, and nearly all of the content flowed out; Figures 2D and 2E show heat-treated cells. The dentate structure on the surface of the cells disappeared, the edge of the cell wall was not clear, the cell membrane of the individual cells injured, and the cell wall appeared wrinkled.

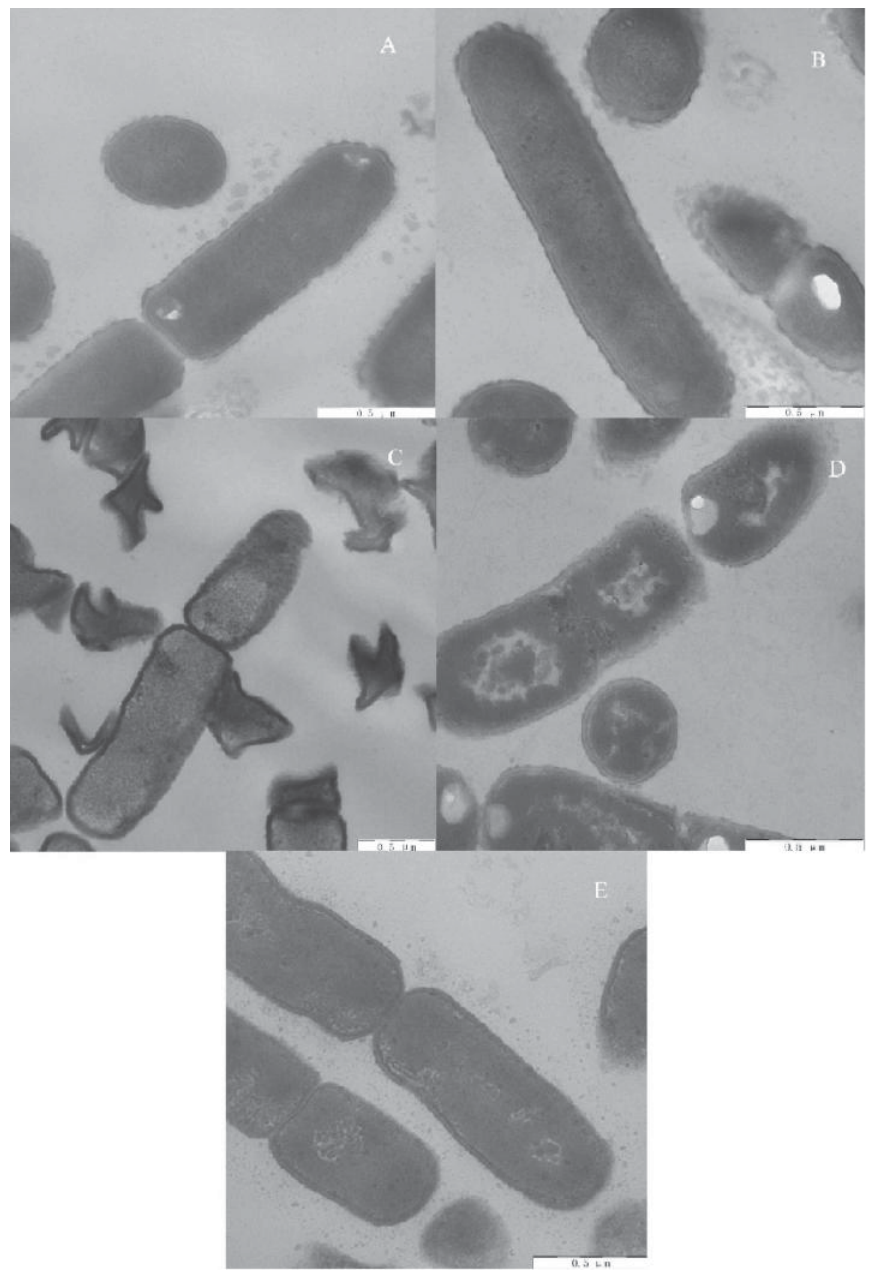

Fig. 2. Effects of different treatments on cell surface structure of $L$. rhamnosus A: Untreated; B: acid-treated; C: alkaline-treated; D: treated at $121{ }^{\circ} \mathrm{C}$; E: treated at $100{ }^{\circ} \mathrm{C}$ 


\subsection{Stability of the PAT-bacterium complex}

The stability of the complex shows the binding mode and strength between toxin and bacterium to some extent (MAнам et al., 2013). The percentage of PAT eluted from the complexes with water is presented in Figure 3. The PAT from the complex was released by the elution process, and the amount of released patulin gradually decreased with the number of elutions (ZHANG et al., 2018). The elution process had different effects on the five groups of complexes, the stability decreased as acid $>121{ }^{\circ} \mathrm{C}>100{ }^{\circ} \mathrm{C}>$ alkali $>$ live bacteria. The results indicate that the treatments enhanced the stability of the complex It was speculated that weak non-covalent bonds formed between toxin and bacterium, and washing destroyed these intermolecular forces (FUCHS et al., 2008). Acid, heat, and other treatments change cell wall structure, leading to different degrees of cross-linking between adjacent cells, cells and PAT, hindering the release of toxins (HERnANDEZ-MENDOZA et al, 2010).

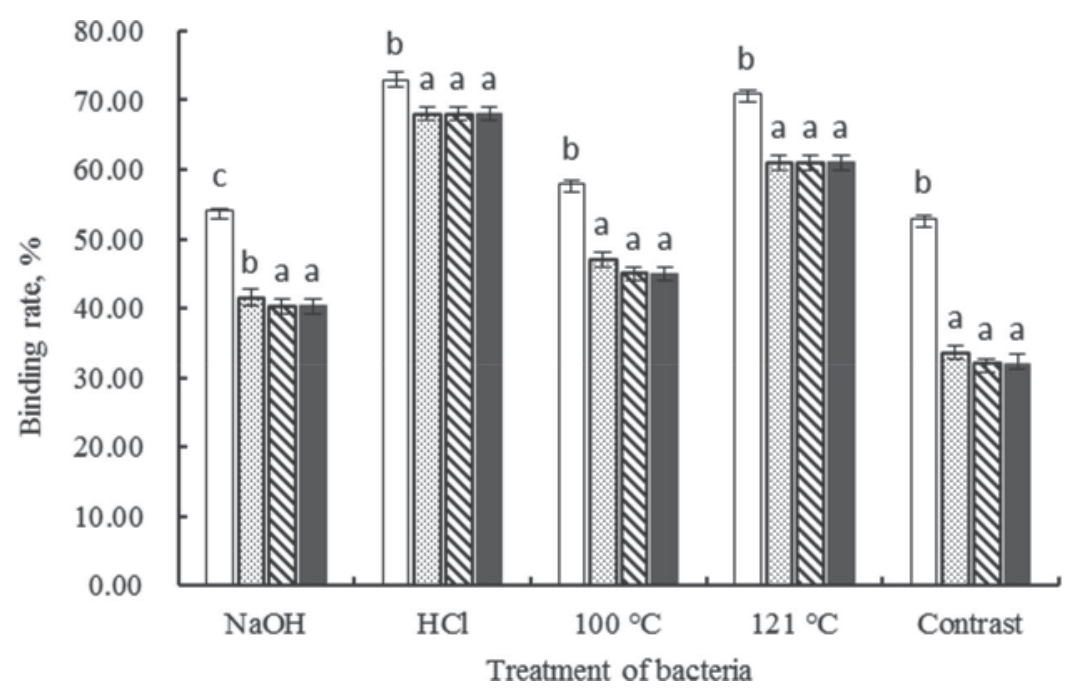

Fig. 3. Effects of elution on the stability of the complex

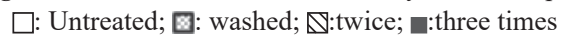

L. rhamnosus is a Gram-positive bacterium with a thick cell wall. This test split the cellular components to study the difference in the ability of single component to adsorb PAT. As shown in Figure 4, the difference in the binding of PAT by different bacterial components was significant $(\mathrm{P}<0.05)$. Both peptidoglycan and $\mathrm{S}$-layer protein showed the ability to bind PAT, but the binding effect was not obvious. According to the results, the binding of PAT by both components was lower than that of the broken cell wall, indicating that the cell adsorption capacity was not only determined by a single component, but also the spatial structure and cross-linking formed between the various substances in the cell wall (GuO et al., 2012).

Carbohydrates in the cell wall had been considered to be key factors affecting the adsorption capacity of bacteria (DOHERTY et al., 2012). LuO and co-workers (2015) believed that the content of 1,3- $\beta$-glucan was closely related to the adsorption capacity of bacteria, affecting the thickness and structure of the cell wall (VAN EMMERIK et al., 2010). Peptidoglycans are formed by the polymerization of acetylglucosamine, acetylmuramic acid, and four to five amino acid short peptides. Gram-positive bacteria have a high degree of cross-linking 
between peptide chains. The numerous peptidoglycan layers form a dense network structure. The interaction between strains and mycotoxins is influenced by peptide chains and amino acids in the peptidoglycan (Zou et al., 2012, ElnEZAmi et al., 2004). The results of this experiment indicate that the cell wall is the main region where adsorption occurs, and the adsorption is independent of the cell membrane. Compared to intact cells, the adsorption capacity of broken cell walls improved. Complex cell wall structure was the basis of adsorption capacity. Loss of cell wall caused a decrease in adsorption rate (HATHOUT et al., 2011). The extraction of a single cell component destroyed the tight network structure in the cell wall. And the loss of specific components of the cell wall led to a decrease in the adsorption capacity of the cell.

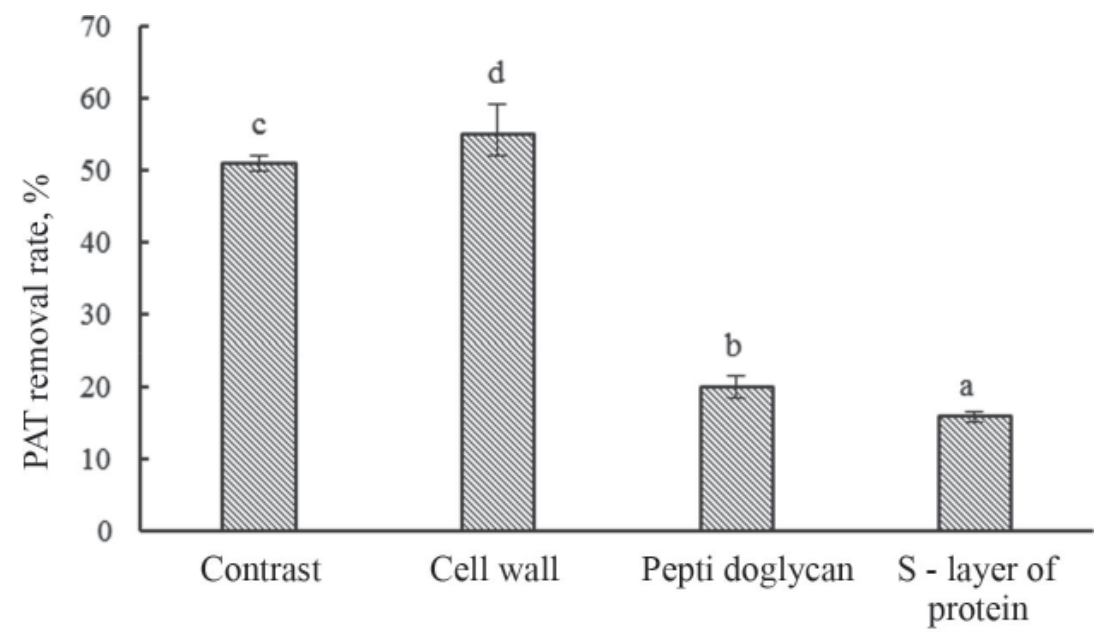

Fig. 4. Effects of different components of L. rhamnosus on patulin binding rate

\subsection{Factors affecting the binding process}

With the increase of cell concentration, PAT-binding significantly increased $(\mathrm{P}<0.05)$ (Fig. $5 \mathrm{~A})$. The binding rates and amounts of toxin by L. rhamnosus at different PAT concentrations are shown in Figure 5B. The binding rate reached its maximum $(53.39 \pm 1.43 \%)$ at PAT concentration of $1000 \mu \mathrm{g} \mathrm{l^{-1 }}$, which might be explained by limited binding sites. The binding of PAT by L. rhamnosus at different $\mathrm{pH}$ values is shown in Figure $5 \mathrm{C}$. The binding rate gradually decreased with increasing $\mathrm{pH}$ values. The optimal $\mathrm{pH}$ was 3.0 , where the binding reached $50.39 \pm 2.09 \%$. This was consistent with the results found in the literature that with higher $\mathrm{pH}$ value, the binding rate was lower (НАTAB et al., 2012a). The binding of PAT by $L$. rhamnosus increased with time during $0-4 \mathrm{~h}$, and the adsorption effect on PAT became stable after $4 \mathrm{~h}$ (Fig. 5D). Thi is consistent with findings of KHOURY and co-workers (2011), that detoxification was a rapid process. The effect of different reaction temperatures on the detoxification effect was significant $(\mathrm{P}<0.05)$ (Fig. 5E), L. rhamnosus had the strongest ability to bind PAT at $37^{\circ} \mathrm{C}$. This result is in contradiction with the findings of KHOURY et al. (2011), who found that the optimum temperature for the binding of aflatoxin and corn erythrotoxin by LAB was $25^{\circ} \mathrm{C}$.

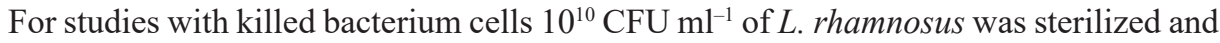
incubated with $1000 \mu \mathrm{g} \mathrm{ml}^{-1}$ PAT for $4 \mathrm{~h}$ at $37^{\circ} \mathrm{C}$, and the binding rate reached $50.9 \pm 1.03 \%$. 

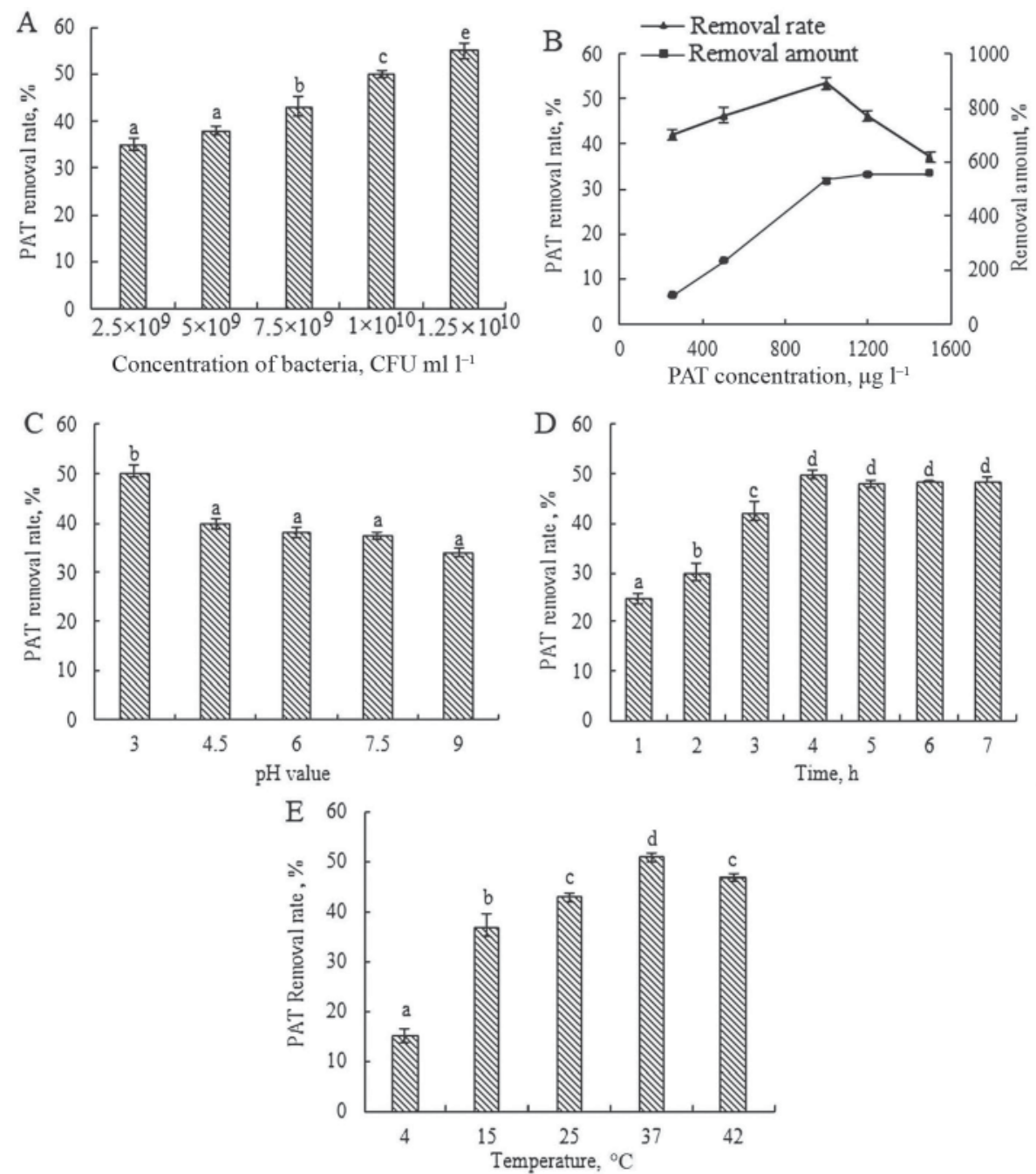

Fig. 5. Effects of different conditions on patulin detoxification ability of L. rhamnosus. A: bacterial concentration; $\mathrm{B}$ : PAT concentration; $\mathrm{C}$ : $\mathrm{pH}$; D: reaction time; E: temperature

\subsection{Binding in apple juice}

It can be seen from Figure 6 that the removal of PAT from apple juice was affected by the quantity of the added inactivated bacterial powder: the higher the dose of the inactivated bacterial powder, the lower the concentration of PAT remaining in the apple juice.

Sensory quality indicators did not change significantly (Table 1 ). The colour value of apple juice increased by $0.5 \%$ and light transmittance by $2.67 \%$, compared to control. It was speculated that the inactivated bacteria powder adsorbed proteins and polyphenols in apple juice, which increased the light transmittance. This could solve the problems of turbidity and browning of apple juice during storage and transportation elegantly (BELTRÁN et al., 2014). The treatment had little effect on the $\mathrm{pH}$ value, total sugar and total acid values of the juice, 
which is consistent with the results of HATAB and co-workers (2012b). There were no significant differences in sensory properties such as acidity, sugar content, light transmittance and soluble solid content of the product after 6 weeks of refrigerated storage.

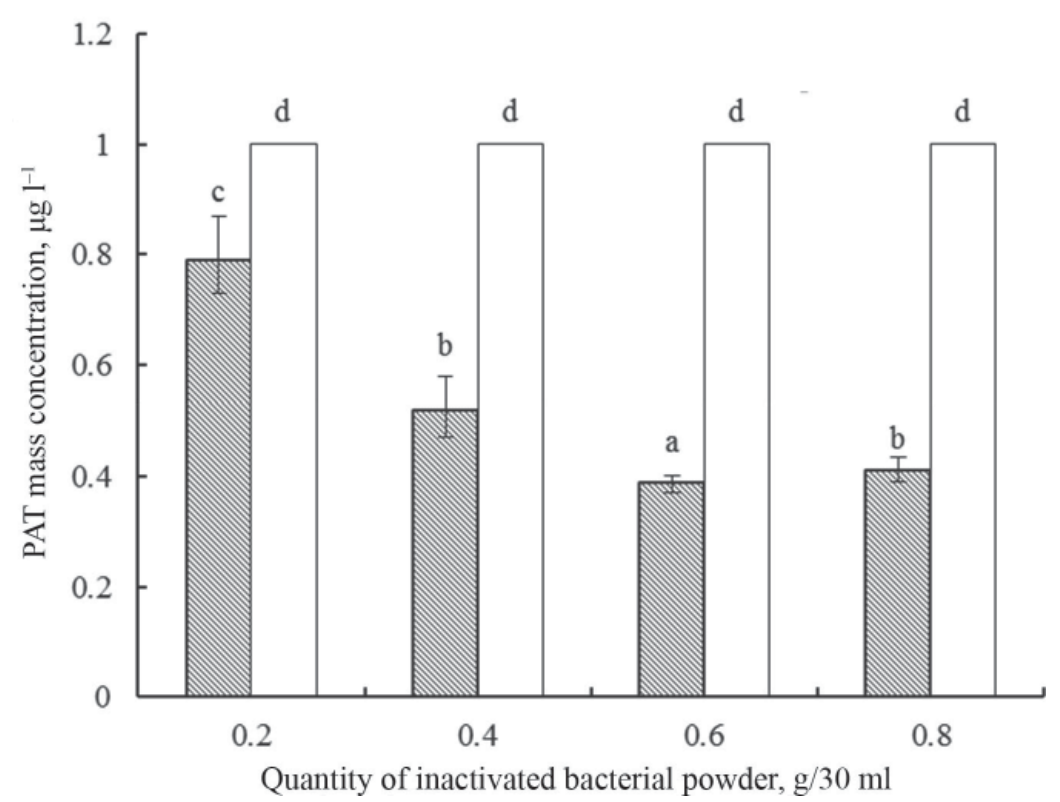

Fig. 6. Effects of inactivated bacterial powder dosage on patulin detoxification in apple juice Note: different letters indicate significant difference between groups $(\mathrm{P}<0.05)$

$\mathbb{N}$ :PAT concentration after adsorption; $\square$ : PAT concentration before adsorption

Table 1. Effects of inactivated bacterial powder on sensory and physicochemical characters of apple juice

\begin{tabular}{lcc}
\hline Parameters & Control $(0 \mathrm{~g})$ & $0.6 \mathrm{~g} / 30 \mathrm{ml}$ \\
\hline Colour value, \% & $72.05 \pm 0.05^{\mathrm{a}}$ & $72.95 \pm 0.05^{\mathrm{a}}$ \\
Light transmittance, \% & $92.27 \pm 0.03^{\mathrm{a}}$ & $94.94 \pm 0.03^{\mathrm{a}}$ \\
$\mathrm{pH}$ & $3.9 \pm 0.01^{\mathrm{a}}$ & $3.9 \pm 0.01^{\mathrm{a}}$ \\
Soluble solids, ${ }^{\circ} \mathrm{Bx}$ & $11.58 \pm 0.01^{\mathrm{a}}$ & $11.97 \pm 0.05^{\mathrm{a}}$ \\
Total sugar, g/100 g & $11.67 \pm 0.02^{\mathrm{a}}$ & $11.65 \pm 0.02^{\mathrm{a}}$ \\
Total acid, g/100 g & $2.12 \pm 0.01^{\mathrm{a}}$ & $2.13 \pm 0.01^{\mathrm{a}}$ \\
\hline
\end{tabular}

Note: same letters indicate that there is no significant difference between groups $(\mathrm{P}>0.05)$.

\section{Conclusions}

The results of this experiment show that different treatments can improve the ability of $L$. rhamnosus to bind PAT. The PAT-binding of L. rhamnosus was reversible, the stability of the complex was poor, and was higher for treated cells than living bacteria. The adsorption was based on cell wall structure. Environmental factors affected the detoxification ability of the 
bacterium. The maximum PAT-binding rate was $53.39 \%$, when the time of mixed cultivation of strain and PAT was $4 \mathrm{~h}$, the reaction temperature was $37^{\circ} \mathrm{C}$, the $\mathrm{pH}$ was 3 , and the initial concentration of PAT was $1000 \mu \mathrm{g} \cdot \mathrm{l}^{-1}$. The addition of $L$. rhamnosus inactivated powder did not affect the quality of the juice product and could effectively bind the PAT in apple juice. The application of L. rhamnosus in other fruit products requires further research.

This research was supported by young innovative talent of general undergraduate colleges in Heilongjiang (UNPYSCT-2016141).

\section{References}

Beltrán, E., IbÁÑez, M., Sancho, J.V. \& Hernández, F. (2014): Determination of patulin in apple and derived products by UHPLC-MS/MS. Study of matrix effects with atmospheric pressure ionisation sources. Food Chem., 142, 400-407.

Bonerba, E., Ceci, E., Conte, R. \& Tantillo, G. (2010): Survey of the presence of patulin in fruit juices. Food Addit. Contam. B, 3, 114-119.

Brackett, R.E. \&. Marth, E.H. (1979): Patulin in apple juice from roadside stands in Wisconsin. J. Food Protect, $42,862-863$.

Cataldo, F. (2008): Ozone decomposition of patulin - a micotoxin and food contaminant. Ozone - Sci. Eng., 30, 197-201.

Chinese Standard SB/T (1994): General test method for fruit juice. SB/T 20203-1994

Doherty, S.B., Auty, M.A., Stanton, C., Ross, R.P., Fitzgerald, G.F. \& Brodkorb, A. (2012): Survival of entrapped Lactobacillus rhamnosus GG in whey protein micro-beads during simulated exvivo gastrointestinal transit. Int. Dairy J., 22, 31-43.

Drusch, S., Kopka, S. \& Kaeding, J. (2007): Stability of patulin in a juice-like aqueous model system in the presence of ascorbic acid. Food Chem., 100, 192-197.

EC (2003): European Commission, Commission Regulation (EC) N-1425/2003 of 11 August 2003 amending regulation (EC) N-466/2001 as regards patulin. O. J. of EU of 12 August $2003 \mathrm{~L}, 203$, pp. 1-3.

Elnezami, H., Polychronaki, N., Lee, Y., Haskard, C., Juvonen, R., Salminen, S. \& Mykkänen, H. (2004): Chemical moieties and interactions involved in the binding of zearalenone to the surface of Lactobacillus rhamnosus strains GG. J. Agr. Food Chem., 52, 4577-4581.

Elsanhoty, R.M., Salam, S.A., Ramadan, M.F. \& BadR, F.H. (2014): Detoxification of aflatoxin M1 in yoghurt using probiotics and lactic acid bacteria. Food Control, 43, 129-134.

Fuchs, S., Sontag, G., Stidl, R., Ehrlich, V., Kundi, M. \& Knasmüller, S. (2008): Detoxification of patulin and ochratoxin A, two abundant mycotoxins, by lactic acid bacteria. Food Chem. Toxicol., 46, 1398-1407.

Guo, C., Yuan, Y., Yue, T., Hatab, S. \& Wang, Z. (2012): Binding mechanism of patulin to heat-treated yeast cell. Lett. Appl. Microbiol., 55, 453-459.

Haskard, C., Binnion, C. \& Ahokas, J. (2000): Factors affecting the sequestration of aflatoxin by Lactobacillus rhamnosus strain GG. Chem-Biol. Interact., 128, 39-49.

Haskard, C.A., El-Nezami, H.S., Kankaanpaa, P.E., Salminen, S. \& Ahokas, J.T. (2001): Surface binding of aflatoxin B1 by lactic acid bacteria. Appl. Environ. Microbiol., 67, 3086-3091.

Hatab, S., Yue, T. \& Mohamad, O. (2012a): Reduction of patulin in aqueous solution by lactic acid bacteria. J. Food Sci., 77, M238-M241.

Hatab, S., Yue, T. \& Mohamad, O. (2012b): Removal of patulin from apple juice using inactivated lactic acid bacteria. J. Appl. Microbiol., 112, 892-899.

Hathout, A.S., Mohamed, S.R., El-Nekeety, A.A., Hassan, N.S., Aly, S.E. \& Abdel-WahHab, M.A. (2011): Ability of Lactobacillus case $i$ and Lactobacillus reuteri to protect against oxidative stress in rats fed aflatoxinscontaminated diet. Toxicon, 58, 179-186.

Hernandez-Mendoza, A., Guzmandepeña, D. \& Garcia, H.S. (2010): Key role of teichoic acids on aflatoxin B1 binding by probiotic bacteria. J. Appl. Microbiol., 107, 395-403. 
Khoury, A.E., Atoui, A. \& Yaghi, J. (2011): Analysis of aflatoxin M1 in milk and yogurt and AFM1 reduction by lactic acid bacteria used in Lebanese industry. Food Control, 22, 1695-1699.

Luo, Y., Wang, J.G., LiU, B., WANG, Z.L., YuAN, Y.H. \& Yue, T.L. (2015): Effect of yeast cell morphology, cell wall physical structure and chemical composition on patulin adsorption. Plos One, 10, e0136045.

Maham, M., Karami-Osboo, R., Kiarostami, V. \& Syed, W.H. (2013): Novel binary solvents-dispersive liquidliquid microextraction (BS-DLLME) method for determination of patulin in apple juice using highperformance liquid chromatography. Food Anal. Method, 6, 761-766.

Ricelli, A., Baruzzi, F., Solfrizzo, M., Morea, M. \& Fanizzi, F.P. (2007): Biotransformation of patulin by Gluconobacter oxydans. Appl. Environ. Microb., 73, 785-792.

Serrano-Niño, J.C., Cavazos-Garduño, A., Hernandez-Mendoza, A., Applegate, B., Ferruzzi, M.G., ... \& GARCíA, H.S. (2013): Assessment of probiotic strains ability to reduce the bioaccessibility of aflatoxin M1 in artificially contaminated milk using an in vitro digestive model. Food Control, 31, 202-207.

VAn EMmeriK, L.C., KuiJPer, E.J., FiJen, C.A., DanKert, J. \& Thiel, S. (2010): Binding of mannan-binding protein to various bacterial pathogens of meningitis. Clin. Exp. Immunol., 97, 411-416.

ZhanG, X., MA, Y. \& YE, G. (2018): Morphological observation and comparative transcriptomic analysis of Clostridium perfringens biofilm and planktonic cells. Curr. Microbiol., 75, 1-8.

Zoghi, A., Khosravi-Darani, K., Sohrabvandi, S., ATtar, H. \& Alavi, S.A. (2017): Effect of probiotics on patulin removal from synbiotic apple juice. J. Sci. Food Agr., 97, 2601-2609.

Zou, Z.Y., He, Z.F., LI, H.J., HAN, P.F., Meng, X. \& ZHANG, Y. (2012): In vitro removal of deoxynivalenol and t-2 toxin by lactic acid bacteria. Food Sci. Biotechnol., 21(6), 1677-1683. 